\title{
Job that fits for graduates in the Asean integration
}

\author{
Glenn L. Velmonte, Ph.D. ${ }^{1}$ \\ ${ }^{1}$ Associate Professor, Cebu Normal University, Cebu City, Philippines \\ Email:velmonteg@cnu.edu.ph \\ https://orcid.org/0000-0002-0145-7809
}

\begin{abstract}
Philippines now faces a big challenge with regards to the labor force. The ASEAN Economic Community was made to integrate the economies of the member-countries. The Philippines before was behind academically because of the curriculum used. To address the problem, the Philippines uses the K-12 Program which is an international standard and what the other members of ASEAN use. So, it is important to know what jobs are in-demand so that the students will take the course for the specific job.

This study is aimed to know the in-demand jobs of the Southeast Asian nations and to help the Filipinos what's the best career path they should take for a bigger chance of getting employed in 2017. This study is only limited not beyond the year 2017. This study will help job-seekers to what jobs they have the best chance being employed.

A quantitative approach was used in this study. Data were acquired from the 10 members of the Association of the Southeast Asian Nations. Those data are the employment, enrolment, and survival rate of the professionals in each country, in which the countries differ. The countries also differ in their supply, skills, wages, and productivity. From all the acquired information, the researchers found out that the Philippines is second in the highest number of unemployed youth and ranks fourth in the employment rate.

The 10 countries also have different in-demand jobs. But all in all, the most in-demand job in Southeast Asia is engineering. This is followed by accounting, teaching, nursing, and IT.
\end{abstract}

Keywords: ASEAN, Economic, Integration, jobs, demand

\section{Rationale}

\section{THE PROBLEM AND ITS SCOPE}

A keen observant may notice why Philippines is lagging behind other countries in terms of educational performance. Because of this, there is job mismatch where education does not meet the need of labor market/industries, which results to the rise of unemployment rate. Filipino graduates working abroad are not at par with local or other foreign counterparts on job qualification. Thus, ASEAN economic integration in 2015 compels the Philippine educational qualification to aim for global comparability.

Theoretical-Conceptual Framework

The ASEAN integration is an imitation of the Bologna Process. The same reason why Asean integration was created. Recall that with the Bologna Process implementation, higher education systems in European countries are to be organized in such a way that:

a. it is easy to move from one country to the other (within the European Higher Education Area) - for the purpose of further study or employment;

b. the attractiveness of European higher education has increased, so that many people from non-European countries also come to study and/or work in Europe;

c. the European Higher Education Area provides Europe with a broad, high-quality advanced knowledge base, and ensures the further development of Europe as a stable, peaceful and tolerant community benefiting from a cuttingedge European Research Area; there will also be a greater convergence between the U.S. and Europe as European higher education adopts aspects of the American system. The only way to measure the quality of education is through its outcome. The Policy-Standard to Enhance Quality Assurance (QA) in Philippine Higher Education Through an Outcomes-Based and Typology-Based QA states that the multiple missions for the Philippine higher education system is to produce thoughtful graduates imbued with 1) values reflective of a humanist orientation 2) analytical and problem solving skills; 3 ) the ability to think through the ethical and social implications of a given course of action; and, 4) the competency to learn continuously throughout life that will enable them to live meaningfully in a complex, rapidly changing and globalized world while engaging their community and the nation's development issues and concerns; 5) To produce graduates with high levels of academic, thinking, behavioral, and technical skills/competencies that are aligned with national academic and industry standards and needs and 
international standards, when applicable; 6) To provide focused support to the research required for technological innovation, economic growth and global competitiveness, on the one hand, and for crafting the country's strategic directions and policies, on the other; and 7) To help improve the quality of human life of Filipinos, respond effectively to changing societal needs and conditions; and provide solutions to problems at the local community, regional and national levels. Each HEI is also measured based on their institutional vision and mission statements. HEls with similar institutional vision and mission statements may have similar and overlapping attributes and quality outcomes. However, HEls may be differentiated functionally along 1) the qualifications and corresponding competencies of their graduates; 2) the nature of the degree programs offered; 3) the qualifications of faculty members; 4) the types of available learning resources and support structures available; and 5) the nature of linkages and community outreach activities.

Those aforementioned criteria are embedded in the instrument used in evaluating a higher institution which applies for the accreditation of their program offerings. As such, the best way to evaluate higher education institution is its level of accreditation.

\section{STATEMENT OF THE PROBLEM}

This study looks into the basic information about the members of the ASEAN community particularly the education sector that might be affected by the implementation of the ASEAN community economic integration.

This study will answer the following questions:

1. What is the profile of the members of the ASEAN countries in terms of:

1.1 population

1.2 . land area

1.3 Income (per capita GNP)

1.4 quality of higher education?

2. What is the percentage of each degree program enrolled by the students of the ASEAN Nations?

3. What is the employability index of the graduates of the members of the ASEAN Nations in terms of number of:

3.1 Employed,

3.2 Underemployed

3.3 Unemployed?

4. How prepared are the Philippine Higher Education Institutions (HEIs) in terms of:

4.1 curriculum

4.2 program offerings

4.3 employability

4.4. Higher Education program initiatives

4.5. PQF (Philippine Quality Framework) and AQRF

(ASEAN Qualifications Reference Framework)

5. What recommendations can be made based on the findings?

\section{SIGNIFICANCE OF THE STUDY}

The ASEAN Economic Community Integration 2015 is now the current issue of Philippine higher education. However, its popularity is not without disadvantages. One of these is that there are only few sources of information regarding this topic. This topic is not widely known but it has a tremendous effect in our lives. The effect would certainly be catastrophic to the country, in general, if the people are not well-informed. The application of this system affects the future of the graduates and the educational system. And in order that Philippine education will have the edge over other countries, it is important to know the entire concept of this Integration. This study helps to circumspect its adverse effect.

All higher education institutions will benefit from the findings in order to prepare for the new market of education. Colleges and universities will be guided on the courses to be offered.

The policy makers will be guided by these findings in crafting a better policy that would adapt to the new trend. The administrators will be guided on the new direction in the integration. Finally, in general, the country will benefit from the study because the findings will reveal basic information about the country-competitor in aspiring which among them will be the best gainer in the ASEAN Economic Community Integration.

\section{DEFINITION OF TERMS}


Integration -- Integration is defined as to put an end to the segregation of and bring into equal membership in society or in an organization.

Economic integration -- The process by which different countries agree to remove trade barriers between them. Trade barriers can be tariffs (taxes imposed on imports to a country), quotas (a limit to the amount of a product that can be imported) and border restrictions. For example, Canada, Mexico and the United States have formed the North American Free Trade Agreement (NAFTA), which reduces trade barriers between the three countries.

Degree program - refers to courses to be taken prior to the giving of an award conferred by a college or university signifying that the recipient has satisfactorily completed a course of study.

Employability index refers to the data showing the number of those who are employed, underemployed, and unemployed?

Employed are those whose jobs match or seemingly in line with the academic degree taken.

Underemployed is when the job does not match with the academic degree taken.

Unemployed are those who earned academic degree but not employed.

Curriculum is the total learning experience provided by a school. It includes the content of courses (the syllabus), the methods employed (strategies), and other aspects, like norms and values, which relate to the way the school is organized.

Program offerings are disciplines of study such as education, arts and sciences, nursing, and etc.

Employability refers to a person's capability for gaining and maintaining employment.

\section{REVIEW OF RELATED LITERATURE AND RELATED STUDIES}

\section{Related Literature}

Prior to ASEAN Economic Integration there are already two agreements of countries to standardize education. The Bologna Process and the Washington Accord attempt to unify education. Both agreements meet without criticisms. Different authors view this in a various ways. Others say integration brings more benefits to the country rather than disadvantages; while others say otherwise. Callaghan (1987) commented on ASEAN Integration in saying that a massive increase of trading lines can surely affect the economy of the country. This massive change will kick-off at the start of the Economic Integration. On the other hand, Widdecombe (1965), already predicts that the export trades will rise above its limits, but domestic trades will be hard work in the future. Thus, integration is a competition among member-country taking into account the surplus and shortage of the country. The excess of one country may be need in the member country which falls short.

\section{Related Studies}

Angela Yung-Chi Hou (2012), in an article "Mutual recognition of quality assurance decisions on higher education institutions in three regions: a lesson for Asia" cross-border higher education resulting in the increased mobility of students, academic staff, programs, institutions and professionals has grown considerably in global times. The question on how to ensure that the quality of academic programs has met the local and international standards simultaneously has become a great challenge in many nations. In recent years, the need for close cooperation of quality assurance agencies and acceptance of review decisions called "Mutual recognition" has been promoted by several international quality assurance networks of higher education. Established in 2003, the European Consortium for Accreditation in higher education (ECA), which aims to achieve mutual recognition of accreditation decisions among member countries, is the first such initiative in the world. Thus, this is a need to create a body that will recognize the quality of the products and this must be represented by the member state. Finally, each state must seek a seat in the accreditation to favour their own state; otherwise, the product may not be recognized.

Senen Perlada, director of the Export Marketing Bureau of the Department of Trade and Industry, said that the priority sectors are: agro-based products, automotives, electronics, fisheries, rubber-based products, textiles and wood-based products for goods, and air transport, eAsean, healthcare, logistics and tourism services. (2014, April 3. 11 Sectors Prioritized in Asean Economic Integration. Sunstar, p.A16). In line with Integration, Honeyman added further that Global competitiveness substantially means able to compete in terms of: numeracy of mathematics, science, language, and information technology. This should be the cornerstone of the Philippine education policy. (Honeyman, Neil. 2014, March 12, globally competitive education. Sunstar, p.A14). In addition, the chairman of Commission on Higher Education, Patricia Licuanan list the Priority Courses for Academic Year 2014-2015 to Academic Year 2017-2018. The data shows that the stakeholders view engineering and agriculture as in-demand in the industry for the next five years. Although there is still high unemployment in the Philippines, these identified courses are important in the future. Besides, this list would balance and distribute proportionally the graduates thereby producing knowledgeable graduates of the different fields. Right now there is great disproportion to the demand and 
supply of laborers which eventually causes the unemployment and underemployment. With no strict measures to combat this problem would eventually worsen the economy during the ASEAN economic integration.

\section{Research Method}

\section{RESEARCH METHODOLOGY}

The study utilizes a combination of descriptive survey and data analysis method of research. A descriptive survey was used to describe and interpret the data gathered to answer the problems. Data will be generated from the internet; such that there will be no questionnaires to be distributed. The main source of the information is the data from the website of the agencies of the ASEAN members. It is so because the nature of the study requires that information should be retrieved through the website of the concerned agencies. As to problem number 4 of this study, the information are by the level of accreditation since instruments of the accreditation determines some aspects of preparedness of the higher institutions.

Research Subjects and Respondents

The subjects of the research are the ASEAN which is composed of ten members, namely: Indonesia, Malaysia, Philippines, Singapore, Thailand, Brunei, Laos, Myanmar, Vietnam, and Cambodia. The study focuses particularly the respective agencies or department of the countries involved which data are necessary to the study. Specifically, the researcher would look into the agency or department of countries in-charged in keeping the profile or information of the country. In the Philippines, the vital source of information important in this study is the NSO (National Statistics Office). Other agencies or departments may also be useful for other source of information. When information is not available by the subject country, or when the information is withheld by the subject country, third country which possesses the information may also be utilized. In the absence or when information which is important in this study cannot be availed by those processes aforementioned, interview with foreign delegates representing the country may be utilized.

\section{Research Environment}

This research utilizes the use of the internet to data mine information that can be retrieved in other countries. The researcher would look into the different agencies of the members of the ASEAN Nations and retrieve necessary information relevant to the study. ASEAN members are Indonesia, Malaysia, Philippines, Singapore, Thailand, Brunei, Laos, Myanmar, Vietnam, and Cambodia. This study will be conducted in the Philippines albeit its subjects are outside it. The reason behind this is the fact that it would be practical to access the information outside the country through the utilization of the internet. Besides, the information in the internet is similar and would render the same result and reliability than actually going to all countries which are members of the ASEAN.

The comparison of the profile of the country is also important to validate the hypotheses of the study. From the data it can be seen the status of the Philippines as compared to other ASEAN members.

\section{Gathering Procedure}

After the approval of the Research Design, the researcher will look into the possible and reliable source of information in the country subject of the study. Extracts information from the ten countries of the ASEAN to come up with a data set and transforms it into graphical representation to make it understandable. Aside from the graphs which clearly show the difference among member-states, a table which also shows the comparison in all aspects vital to Integration 2015 is also shown. From there, the next step to be done is to generate conclusion. The above process is in line with database and data management, data pre-processing, and inference considerations.

\section{Statistical Treatment of Data}

The results were tallied and tabulated. The researcher uses data mining technique in gathering information and applies correlation analyses through the use of MINITAB software. The research basically utilizes correlation to compare and contrast the countries of the ASEAN nations in the aspect of education and employability brought about by Economic Integration. Regression is also employed to various variables to see the difference between and among the variables.

\section{PRESENTATION, ANALYSIS AND INTERPRETATION OF DATA}

This chapter includes the presentation, analysis and interpretation of data gathered by the researchers from the secondary data used. This chapter also contains the presentation of data in tabular and figure form along with its interpretation.

\section{A. RESPONDENT PROFILES AND THEIR EDUCATION SYSTEM BRUNEI DARUSSALAM}

Brunei Darussalam is the smallest ASEAN member state with a population of over 400,000. Its per capita GDP in 2011 was US\$38,703, making it the second highest for any of the ASEAN member states. Brunei was considered by World Bank as 'high income'. With a view of securing the nation's future in global economy, Brunei Darussalam is now investing strongly in its education system. (ASEAN State Education Report, 2014) 
The Education System of Brunei Darussalam has a 6-5-2 structure, that is, six years of primary, five years of secondary and two years of pre-university studies. Under the Compulsory Education Act of 2011, all children aged 6 to 15 years old must be educated of at least 9 years.

With the data retrieved from ASEAN State of Education Report 2013, Table 2 shows the Net enrolment rate and Table 3 shows the Survival Rate in Brunei Darussalam.

\begin{tabular}{|c|c|c|c|}
\hline & 2009 & 2010 & 2011 \\
\hline Primary Education & 97.5 & 97.36 & 97.58 \\
\hline Secondary Education & 89.88 & 90.11 & 91.19 \\
\hline Tertiary Education & 17.83 & 16.84 & 20.15 \\
\hline \multicolumn{4}{|c|}{$\begin{array}{l}\text { SOURCE: ASEAN State Education Report } 2013 \\
\text { Table 2. Net Enrolment Rate in Percentage in Brunei }\end{array}$} \\
\hline & 2009 & 2010 & 2011 \\
\hline Primary Education & 98 & 99 & 100 \\
\hline Secondary & 75 & 92 & 95 \\
\hline University Qualifications & 11 & 11 & 11 \\
\hline
\end{tabular}

SOURCE: ASEAN State Education Report 2013

Table 3. Survival Rates in Percentage in Brunei

It can be seen in the two data that the Enrolment Rate in Brunei Darussalam is increasing every year which means the students enrolling is increasing every year. With regards to the Survival Rate, it can be observe that in the Secondary level, it has a big jump from 2009 with $75 \%$ to $92 \%$ in 2010 . This can only mean that students graduating from the Secondary level are increasing.

However, when it comes to curriculum preferences, the Table 4 shows that males prefer TechnicalVocational route rather than the Higher Education. Higher Education refers to Colleges of Higher Education and Universities.

\begin{tabular}{lllll}
\hline YEAR & HIGHER & EDUCATION & TECHNICAL/ & VOCATIONAL \\
\hline & MALE & FEMALE & MALE & FEMALE \\
$\mathbf{2 0 0 6}$ & 1687 & 3138 & 1678 & 782 \\
$\mathbf{2 0 0 7}$ & 1815 & 3177 & 1754 & 1131 \\
$\mathbf{2 0 0 8}$ & 1790 & 3227 & 1796 & 1202 \\
\hline
\end{tabular}

SOURCE: Ministry on Education (2008)

Table 4. Gender Distribution in Technical-Vocational and Technical Education in Brunei

\section{CAMBODIA}

Cambodia is considered as one of the least developed ASEAN member state. It has a population of around $16,000,000$.Its GDP per capita was only US\$879 in 2011 despite the impressive economic rates since mid-1990s. It is a youthful nation with almost one-third of its population aged 0-14 years old.(ASEAN State Education Report, 2014)

The Education System of Cambodia has a 6-3-3 pattern which consists of six years of primary, three years of lower secondary and three years of upper secondary studies. It is a must that children aged 6 to 15 attend school. About 3.1 million children were enrolled in primary schools, of who the majority are from rural areas.

The Ministry of Education, Youth and Sport along with stakeholders in the community established a community learning center in TbongKhmum village, Kong Pisey district, KongpongSpeu province on June 1, 2011. This is an example of sustainable operation. The community helped with repairing and furnishing additional equipment for study in occupational skills such as tailoring, traditional music and wedding planning.

It can be seen in the data, the number of female enrolled in the community learning centers increased from 1,438 in 2006 to 6,217 in 2013 . The reason behind this increase is because of the skills offered were appealing to the females and responded to the labour market demands.

In Table 6, it show the number of students enrolled in Higher Education over time. It can be seen that the female students enrolled have increased which means that more female students have access in Higher Education. 


\begin{tabular}{lllllll}
\hline Bachelor & $\begin{array}{l}\text { Degree } \\
\text { Public }\end{array}$ & $\begin{array}{l}\text { Students } \\
\text { Institutions }\end{array}$ & in & Bachelor in & $\begin{array}{l}\text { Degree } \\
\text { Private }\end{array}$ & $\begin{array}{l}\text { Students } \\
\text { Institutions }\end{array}$ \\
\hline & Total & Female & \%Female & Total & Female & $\%$ Female \\
$\mathbf{2 0 0 0 - 0 1}$ & 26,361 & 5,538 & 21.00 & 5,579 & 1,313 & 23.53 \\
$\mathbf{2 0 0 1 - 0 2}$ & 23,340 & 7,071 & 30.29 & 8,400 & 2,080 & 24.76 \\
$\mathbf{2 0 0 2 - 0 3}$ & 23,481 & 7,288 & 31.03 & 17,828 & 5,178 & 29.04 \\
$\mathbf{2 0 0 3 - 0 4}$ & 25,201 & 8,335 & 33.07 & 19,654 & 5,751 & 29.26 \\
$\mathbf{2 0 0 4 - 0 5}$ & 22,433 & 7,725 & 34.43 & 25,098 & 7,515 & 29.94 \\
$\mathbf{2 0 0 5 - 0 6}$ & 31,241 & 10,883 & 34.83 & 43,622 & 13,748 & 31.51 \\
$\mathbf{2 0 0 6 - 0 7}$ & 38,373 & 13,714 & 35.73 & 53,967 & 18,776 & 34.79 \\
$\mathbf{2 0 0 7 - 0 8}$ & 46,375 & 16,900 & 36.44 & 63,695 & 23,304 & 36.58 \\
$\mathbf{2 0 0 8 - 0 9}$ & 55,576 & 21,381 & 38.47 & 81,677 & 31,426 & 38.47 \\
$\mathbf{2 0 0 9 - 1 0}$ & 67,183 & 26,201 & 38.99 & 94,333 & 37,461 & 39.71 \\
$\mathbf{2 0 1 0 - 1 1}$ & 80,606 & 31,609 & 39.21 & 105,312 & 42,216 & 40.09 \\
$\mathbf{2 0 1 1 - 1 2}$ & 90,171 & 36,711 & 40.71 & 117,495 & 46,752 & 39.79 \\
$\mathbf{2 0 1 2 - 1 3}$ & 96,460 & 37,444 & 38.81 & 119,593 & 48,791 & 40.79 \\
\hline
\end{tabular}

\section{SOURCE: EMIS, MoEYS}

Table 6. Bachelor Degree in Higher Education in Cambodia

\section{INDONESIA}

An archipelago of over 17,000 islands, Indonesia has a population of over 250,000,000. Being an archipelago, it is a challenge for Indonesia in delivering a well-integrated education system. Its level of GDP per capita was US\$3,563 in 2011, and the World Bank classifies Indonesia as 'middle-income'.

In Indonesia, the Education System structure follows the pattern of 6-3-3, that is, six years of primary, three years of lower secondary and three years of upper secondary studies. Indonesia's school system is considered as the fourth largest in the world. It has over 50 million students with about three million teachers and more than 300,000 schools.

The Table 7 contains the Total Enrolment and Gross Enrolment Rate (GER) in Indonesia for the year 2009 to 2010 and 2012 to 2013.

\begin{tabular}{lll}
\hline & $\mathbf{2 0 0 9 - 2 0 1 0}$ & $\mathbf{2 0 1 2 - 2 0 1 3}$ \\
\hline Public & $1,636,122$ & $1,649,267$ \\
Private & $2,451,451$ & $3,645,869$ \\
MORA & 503,439 & 653,846 \\
State & 66,535 & 103,072 \\
Total & $4,657,547$ & $6,052,054$ \\
\hline
\end{tabular}

SOURCE: GER and NER of ECE, Primary, Secondary and Higher Education 2009/2010 and 2012/2013, MOEC

Table 7. Total Enrolment and Gross Enrolment Rate (GER) in Indonesia

It can be seen that the number of students enrolled in Indonesia is impressively increasing. In Table 8, it shows the Survival Rates of students in the three level of education.

\begin{tabular}{llll}
\hline & $\mathbf{2 0 0 9}$ & $\mathbf{2 0 1 0}$ & $\mathbf{2 0 1 1}$ \\
\hline Primary & 94.16 & 89.36 & 95.3 \\
Lower Secondary & 99.26 & 96.72 & 97.68 \\
Upper Secondary & 95.90 & 96.79 & 96.58 \\
\hline
\end{tabular}

SOURCE: ASEAN State of Education Report 2013

Table 8. Survival Rates in Percentage of Indonesia

LAOS

Lao People's Democratic (Lao PDR) was classified by World Bank as 'lower middle income' with its GDP per capita level of $\$ 1,279$ in 2011. Lao PDR has a total population of almost 7,000,000. Laos has at least 49 different ethnic nationalities and some communities were remote, thus, challenging the government in delivering of education, following a curriculum that is relevant to the whole country.

In Laos, their Education System follows the 5-4-3 pattern which consists of five years of primary, four years of lower secondary and three years of upper secondary studies. Primary School for children is compulsory.

\section{MALAYSIA}


Malaysia has a total population of about $31,000,000$. Its economy is rapidly expanding and its level of GDP per capita in 2011 is US\$9,941 which makes it a 'upper middle income' by World Bank.

The Education System of Malaysia has a pattern of 6-3-2. It consists of six years of primary schools, three years of lower secondary school and two years of upper secondary school.

Due to the commitment of the Government of Malaysia to education, Malaysia continues to expand the access to students to other levels of education, which in turn, a great majority of students now move on to secondary education with near universal lower secondary education. From 45 percent in the 1980's, the enrolment rate in the upper secondary education increases to 82 percent today. There are also an increasing number of students who pursues their post-secondary and tertiary education.

In Table 11, the number of enrolled students in different levels is shown while the Survival Rates of Students in Malaysia is shown in Table 12.

\begin{tabular}{ll}
\hline Level & Total \\
\hline Preschool & 200,684 \\
Primary & $2,685,403$ \\
Secondary & $2,188,525$ \\
Overall Total & $5,074,612$ \\
\hline
\end{tabular}

SOURCE: DATA APDM 31 MAY 2016

Table 11. Number of Students (Enrolled) in Malaysia

\begin{tabular}{lllll}
\hline & $\mathbf{2 0 0 9}$ & $\mathbf{2 0 1 0}$ & $\mathbf{2 0 1 1}$ & $\mathbf{2 0 1 2}$ \\
\hline Primary & 98.80 & 97.17 & 98.70 & 99.06 \\
Lower Secondary & 98.37 & 96.20 & 96.27 & 96.28 \\
Upper Secondary & 96.32 & 96.70 & 96.58 & 97.05 \\
\hline
\end{tabular}

SOURCE: ASEAN State of Education Report 2013

Table 12. Survival Rates in Percentage in Malaysia

\section{MYANMAR}

With a total population of over 54,000,000, Myanmar is considered as the second largest in Southeast Asia. Its GDP per capita is only US\$875 in 2011. It has 135 ethnic groups which is a distinct characteristic of Myanmar because of its ethnic diversity.

Myanmar follows the pattern 5-4-2 in their Education System, that is, five years of primary education, four years of lower secondary and two years of upper secondary. However, this structure is under review and to be replaced with a 5-4-3 structure.

Table 13 shows the Net Enrolment Rate in Myanmar and Table 14 contains the Survival Rate.

\begin{tabular}{lllll}
\hline & $\mathbf{2 0 0 9}$ & $\mathbf{2 0 1 0}$ & $\mathbf{2 0 1 1}$ & $\mathbf{2 0 1 2}$ \\
\hline Primary & 83.94 & 84.13 & 84.61 & 84.60 \\
Secondary & 39.57 & 41.15 & 41.61 & 43.77 \\
\hline
\end{tabular}

SOURCE: ASEAN State of Education Report 2013

Table 13. Net Enrolment Rate in Percentage in Myanmar

\begin{tabular}{lllll}
\hline & $\mathbf{2 0 0 9}$ & $\mathbf{2 0 1 0}$ & $\mathbf{2 0 1 1}$ & $\mathbf{2 0 1 2}$ \\
\hline $\begin{array}{l}\text { University } \\
\text { Qualification }\end{array}$ & 73.7 & 78.35 & 80.64 & 79.96 \\
\hline
\end{tabular}

SOURCE: ASEAN State of Education Report 2013

Table 14. Survival Rates in Percentage in Myanmar

It can be seen that the survival rate of students in the university qualification has a decent value and is increasing over time.

\section{PHILIPPINES}

The Philippines is an archipelago with over 7,000 islands. It has a total population of over 103,000,000. Its GDP per capita in 2011 was US\$2,341. It is a multi-linguistic country with thirteen common languages with Filipino as its national language.

Philippines' Education System has a pattern of 6-4-2, which recently switches from a ten-year curriculum to twelve-year curriculum. It consists of six years of elementary school, four years of junior high school and two years in senior high school. 
The education system of Philippines is also called $\mathrm{K}$ to 12 . Under this curriculum, a tech-voc track will be offered at the junior and senior high school levels. Graduates from this program are expected to be equipped and are employable when they exit the Grade 10 and 12 through National Certification I and II.

Figure 2 shows the Students in every Tech-Voc-Subject in Public Schools in the School Year 2012-2013 while Figure 3 shows the Certified Skilled or Tech-Voc Workers by Sectors in the year 2012.

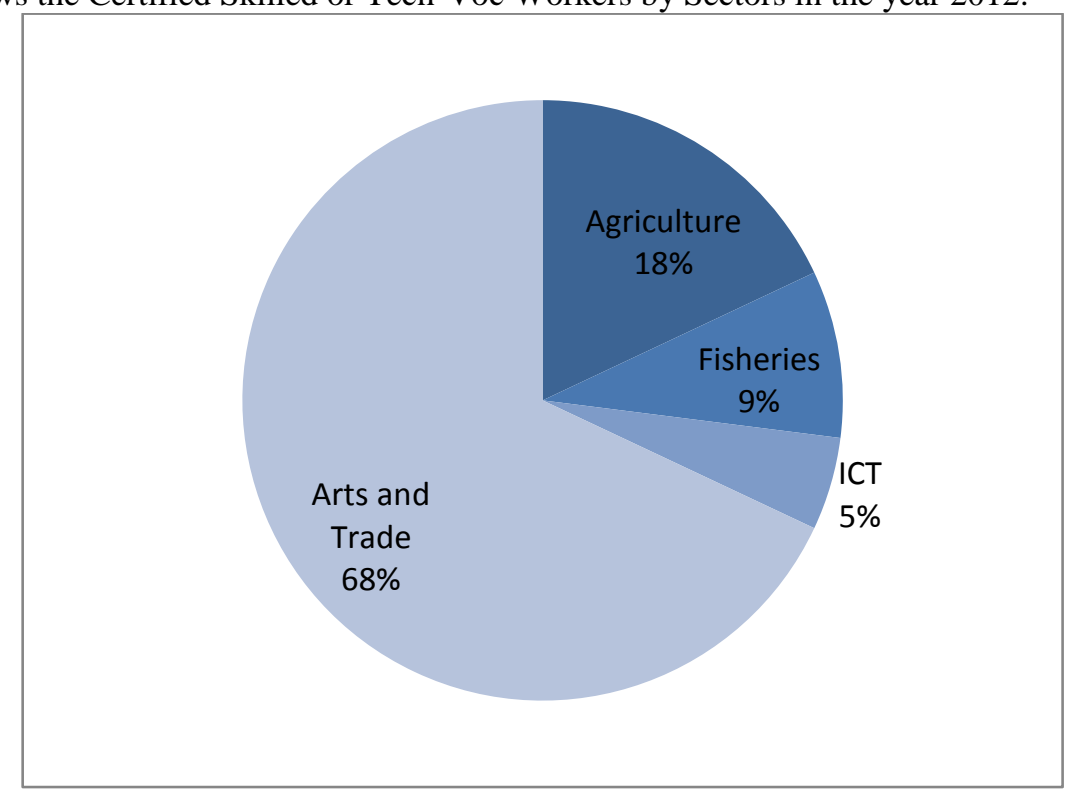

SOURCE: Research and Statistics Division, DepEd

Figure 2. Percentage of Students per Tech-Voc-Subject, Public Schools, SY 2012-2013

\section{SINGAPORE}

Singapore has a population of over 5,700,000 and has the highest GDP per capita level with US\$50,130 in 2011 of any ASEAN member states. It is a very competitive nation and was ranked as second out of 144 on its global competitiveness index by the World Economic Forum.

The Education System of Singapore follows the pattern of 6-4-2, that is, six years of primary, four years of secondary and two years of pre-university studies. They also engage in the delivery of degree programs offered by foreign universities.

Table 15 shows the Net Enrolment Rate and Table 16 shows the Survival Rates of Students in Singapore.

\begin{tabular}{lllll}
\hline & $\mathbf{2 0 0 9}$ & $\mathbf{2 0 1 0}$ & $\mathbf{2 0 1 1}$ & $\mathbf{2 0 1 2}$ \\
\hline Primary & 96.8 & 100 & 100 & 100 \\
$\begin{array}{l}\text { Secondary } \\
\begin{array}{l}\text { Post-secondary } \\
\text { non-tertiary }\end{array}\end{array}$ & 95.2 & 98.3 & 98.8 & 98.8 \\
Tertiary & 74.6 & 73.5 & 78.5 & 87.5 \\
\hline SOURCE: ASEAN State & & & .72 .0 \\
\hline
\end{tabular}

SOURCE: ASEAN State of Education Report 2013

Table 15. Net Enrolment Rate in Percentage in Singapore

\begin{tabular}{lllll}
\hline & $\mathbf{2 0 0 9}$ & $\mathbf{2 0 1 0}$ & $\mathbf{2 0 1 1}$ & $\mathbf{2 0 1 2}$ \\
\hline Primary & 99.9 & 99.9 & 99.9 & 100 \\
Secondary & 99.2 & 99.2 & 99.3 & 99.3 \\
\hline
\end{tabular}

SOURCE: ASEAN State of Education Report 2013

Table 16. Survival Rates in Percentage in Singapore

It can be seen that Singapore has an impressive Net Enrolment rate in Primary level with a perfect score of 100 percent. The number of students is also increasing every year. The survival rates also reflect a positive image to Singapore.

\section{THAILAND}


Thailand has a population of over $68,000,000$ with a GDP per capita of US\$5,116 in 2011 . It ranked $38^{\text {th }}$ in the world in terms of global competitiveness and was considered by World Bank as 'upper middle income'. Its median age is 35.1 years which is older than other ASEAN member states.

In regards to their Education System, Thailand follows the pattern 6-3-3 which consists of six years of primary, three years of lower secondary and three years in upper secondary studies.

In Figure 4, the Enrolment of Students classified by level of Education in the year 2013 is shown.

SOURCE: Implementation Guidelines for Supporting Education acts from Kindergarten through the Basic Education Level in FY 2013

Figure 4. Students Enrolment Classified by Level of Education in 2013

From a report by the Basic Education Commission, it concludes that Thailand has successfully expanded the access of education to their citizens with an increase in the average number of years of education among those people who aged 16 to 69 to 8.3 in 2010 from 5.3 in the past years. The dropout rate also decreases.

Table 17 contains the number of students in Formal School System according to their Grade, Level and Type of Education in the Academic Year 2012.

\begin{tabular}{ll}
\hline Pre-primary & $\mathbf{1 , 7 9 9 , 1 2 5}$ \\
\hline Primary & $4,935,721$ \\
Lower Secondary & $2,497,692$ \\
Upper Secondary & $2,141,289$ \\
Under graduate degree and below & $2,357,831$ \\
Graduate & 199,437 \\
\hline
\end{tabular}

SOURCE: 2012 Statistic in Brief, Office of the Permanent Secretary, Ministry of Education

Table 17. Number of Students in the Formal School System by Grade, Level and Type of Education: Academic Year 2012

\section{VIETNAM}

With a population of almost $650,000,000$, Vietnam had a GDP per capita in 2011 of US\$1,403 and was classified by World Bank as a 'lower-middle-income'. With the combined efforts of the education sector, the local authorities, and other institutions, the overall quality of education in Vietnam has increased since 2000.

With a 5-4-3 pattern in education system, students in Vietnam undergoes five years in primary, four years in lower secondary and two years in upper secondary studies. In higher education, about $16 \%$ of their students enrolled in private universities or college.

Table 18 shows the Net Enrolment Rate while Table 19 shows the Survival Rate of students in percentage in Vietnam.

\begin{tabular}{llll}
\hline & $\mathbf{2 0 0 9}$ & $\mathbf{2 0 1 0}$ & $\mathbf{2 0 1 1}$ \\
\hline Primary & 98.5 & 98 & 99 \\
Secondary & 84.96 & 85.09 & 87.24 \\
Tertiary & 51.73 & 52.59 & 54.25 \\
\hline
\end{tabular}

SOURCE: ASEAN State of Education Report 2013

Table 18. Net Enrolment Rate in Percentage in Vietnam

\begin{tabular}{l|lll}
\hline & $\mathbf{2 0 0 9}$ & $\mathbf{2 0 1 0}$ & $\mathbf{2 0 1 1}$ \\
\hline Primary & 91.32 & 92.16 & 92.08 \\
Lower Secondary & 77.99 & 79.12 & 81.32 \\
Upper Secondary & 76.23 & 79.82 & 82.47 \\
\hline
\end{tabular}

SOURCE: ASEAN State of Education Report 2013

Table 19. Survival Rate in Percentage in Vietnam

With the above information, it is showed that most of ASEAN member states has a 11-year curriculum or 12-year curriculum which is the reason for the Philippines to restructure their education system from 10-year curriculum to 12-year curriculum. Also, from the gathered secondary data, it can be seen that if all the students from each member states are combined, a big population of students would show how hard the competition from different ASEAN member states is when it comes to job-seeking.

\section{B. EMPLOYMENT RATE OF ASEAN MEMBER STATES}


In Table 20, Labour Force and Labour Productivity along with the Educational and Skills Development and Average Money Wage of the ten-member states are shown.

\begin{tabular}{|c|c|c|c|c|c|c|}
\hline & \multirow[t]{2}{*}{$\begin{array}{l}\text { Labour } \\
\text { Force } \\
(000 s)^{(a)}\end{array}$} & Education & \multicolumn{2}{|c|}{$\begin{array}{c}\text { and } \\
\text { Development }\end{array}$} & \multirow[t]{2}{*}{$\begin{array}{l}\text { Average } \\
\text { Money } \\
\text { Wage }\end{array}$} & \multirow{2}{*}{$\begin{array}{l}\text { Labour } \\
\text { Productivity } \\
\text { (constant } \\
2005 \\
\text { International } \\
\$)^{(d)}\end{array}$} \\
\hline & & $\begin{array}{l}\text { Literacy } \\
\text { rate, ages } \\
15+(\%)\end{array}$ & $\begin{array}{l}\text { TVET } \\
\text { enrolment } \\
\text { rate }(\%)\end{array}$ & $\begin{array}{l}\text { Tertiary } \\
\text { gross } \\
\text { enrolment } \\
(\%)\end{array}$ & & \\
\hline Brunei & 186 & 95.4 & 11.4 & 24.3 & --- & 100,015 \\
\hline Cambodia & 7400 & 73.9 & 2.3 & 15.8 & 121 & 3,989 \\
\hline Indonesia & 118,193 & 92.8 & 18.0 & 27.2 & 174 & 9,848 \\
\hline Lao PDR & 3,080 & 72.7 & 0.8 & 16.7 & 119 & 5,396 \\
\hline Malaysia & 13,785 & 93.1 & 6.8 & 36.0 & 609 & 35,751 \\
\hline Myanmar & 30,121 & 92.7 & --- & 13.8 & --- & 2,828 \\
\hline Philippines & 41,022 & 95.4 & --- & 28.2 & 206 & 10,026 \\
\hline Singapore & 3,444 & 95.9 & 11.6 & --- & 3,547 & 98,072 \\
\hline Thailand & 39,398 & 93.5 & 15.4 & 51.4 & 357 & 14,754 \\
\hline Vietnam & 53,246 & 93.4 & --- & 24.6 & 181 & 5,440 \\
\hline
\end{tabular}

SOURCE: ILO and ADB

Table 20.Selected labour market indicators in ASEAN, most recent year

In Table 20, it can be seen that the ASEAN member states differ in terms of supply, skills, wages and productivity. Singapore, according to the data, has the highest money wage while Lao PDR has the lowest. In regards with the Labour productivity, Brunei is the highest, followed by Singapore and then Malaysia. It can be observed that Productivity varies greatly and correlates with the skills of the workers.

In Figure 5, the unemployment rate of each member states is shown.

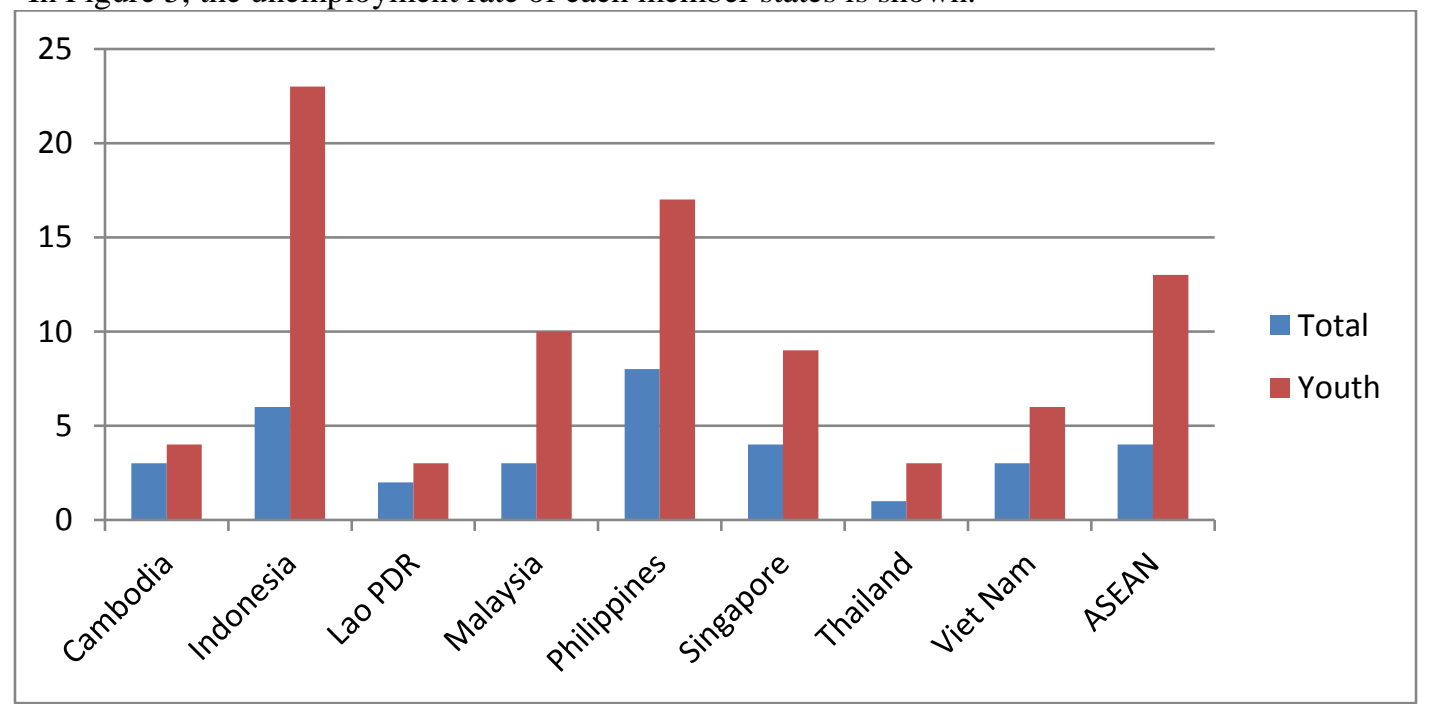

SOURCE: ASEAN COMMUNITY 2015

Figure 5. Unemployment rate, total and youth, most recent year (per cent)

It can be seen from the data that a lot of Indonesian youths are unemployed, followed by the Filipinos while the Lao PDR and Thailand has the lowest number of unemployed youths.

The employment rate is shown in Table 21.

\begin{tabular}{lllll}
\hline & & TOTAL & & 2013 \\
\hline & 2010 & 2011 & 2012 & --- \\
BRUNEI & --- & 183 & --- & --- \\
INDONESIA & --- & --- & 7,197 & 112,760 \\
\hline
\end{tabular}




\begin{tabular}{lllll}
\hline LAO PDR & 3,021 & --- & --- & --- \\
MALAYSIA & 11,900 & 12,284 & 12,723 & 13,210 \\
MYANMAR & --- & --- & -- & 37,917 \\
PHILIPPINES & 36,035 & 37,192 & 37,600 & 2,056 \\
SINGAPORE & 1,963 & 1,999 & 2,041 & 39,112 \\
THAILAND & 38,692 & 39,317 & 39,578 & 52,208 \\
VIETNAM & 49,494 & 50,679 & 51,422 & - \\
\hline
\end{tabular}

Table 21. Employment rate in 2010-2013 (thousand)

SOURCE: ASEAN Community 2015

In relation to the total population of each ASEAN member states, Indonesia has the largest population and also has the largest employment rate followed by Vietnam which has the third largest population. Philippines which has the second largest population falls fourth in the employment rate.

With the above information, it can be seen that even though the Philippines has the second largest population, it is still behind in regards to employment rate. This just implies that the unemployment rate of the Filipinos is high. With the ASEAN Integration, this is quite concerning.

\section{IN-DEMAND JOBS IN THE ASEAN-MEMBER STATES}

The researchers, to know the in-demand jobs in each ASEAN member states, have gathered information from trusted and reliable sources online and these are the secondary data they have gathered.

"Brunei needs more male youths to pursue a career in nursing," HjhSiti Mariam said, the Deputy Permanent Secretary of Health (Administration and Finance) in The Brunei Times. She also said that Brunei needs more male nurses to cater the male patients. (2015)

Cambodian students, on the other hand, chose to study accounting, the second most popular area of focus after English according to statistics from the Ministry of Education, Youth and Sports. However, according to National Employment Agency, while those people who seeks accounting, audit and taxation jobs constitutes to 13.5 percent when such jobs only has 5.8 percent of employer needs. (2013)

Chemistry, physics, biology, design, geography, sociology, psychology, fine arts and public administration, on the other hand, are less popular with less than 1,000 students enrolled which has the possibility to be in-demand because according to Kieng Rotana, vice president of Pannasastra University of Cambodia, "Students who choose subjects that few are interested in will easily get a high income since its demand in the market." Professor Som Chan Sovandra, the vice director of the psychology department at the Royal University, on the other hand, said, "In the Cambodian context, there are a lot of jobs available for psychology students." (Phearon and Sokunthea, 2013)

Regarding Indonesia, a special professional recruitment firm Robert Walters' director Rob Bryson told The Jakarta Post that, "A good command of written and spoken English is a qualification job-seekers looking to join multinationals in Indonesia must possess. As more companies work toward increased cohesion among business units, professionals who understand the business partnering role of their function are highly sought after." Bryson also said that there is a high demand for skills among accounting and finance candidates, risk and compliance sector. There will also be more job opportunities for asset managers, investment bankers and insurance specialist. (2015)

For Lao PDR, according to Labour Minister OnechanhThammavong, it needs to bring in 70,000 more foreign for the country has a shortage of skilled labour. She added that with the lack of trained domestic workforce, 90,000 foreign workers are required to be employed to meet the demands of business operating in the country. (Vandenbrink, 2013)

A senior adviser to the Lao National Chamber of Commerce and Industry shared in the business forum in Vietiane that the country needs more than 31,000 workers in the garment, processing, tourism, steel, furniture, and construction industries. (2013)

The most in-demand jobs in Malaysia are taken from a data compiled by human resource and jobstreet.com.my. Some of these jobs are Chief Financial Officer, HR Business Partners, Compensation and Benefits Specialist, IT Support Specialist, Software Developer, Engineering Manager (oil gas), Development Geologist, Drilling Engineer, Sales Manager, Social Media Manager and Business Development Manager. (2013)

In an article written by JafwanJaafar, a list of in-demand jobs in Malaysia is also given. Some of the jobs that are included in the list are Data Scientist, Web Designers and Developers, Environmental and Waste Management Engineers, Personal Financial Advisers, Personal and Home Care Aides, Marketing Managers and Information Security Analyst. (2016)

With Myanmar, Lynette Chong, Marketing Director of work.com.mm said that, "Myanmar is opening up and thousands of companies are flocking into this beautiful country to become the first mover in their respective 
industry. What we are seeing now is impressive growth in the job market. Many industries are hiring at the moment especially in the banking and telecommunications sector." (2015)

The most vacancies by job categories in Myanmar are Accounting, Sales, IT/Software, Education/Training and Admin. The top hiring Industries, on the other hand, are Computer/IT, NGO/INGO, Construction and Telecommunication services.

Henry Motte-Munoz, following the list of the Department of Labour and Employment, has compiled in his article the in-demand yet hard-to-fill occupation in the Philippines in the year 2013-2020. The kinds of people that are included in the list are the following: Doctors, Engineers, Accountants, Computer Programmers, Draftsman, Animators, Agriculturists, Electricians and Teachers. (2016)

Josh Bianc, in his article written, stated that sugarcane farming landed as the second in-demand job in the Philippines, as what Phil-job.net provides while Business Process Outsourcing or BPO is the most in-demand job. Other in-demand jobs in the country are Domestic Helpers, Service Crew, Commercial Sales Representatives, Customer Service Assistants, Credit and Collection Specialist, Cashiers, Staff Nurses, Cooks, Sewers, Production Machine Operators, Salesclerk, Waiter, Metal Arc Welder and Security Guard. (2016)

For Singapore, according to a new report by staffing firm Kelly Services, the highest-paying jobs are in these five sectors: information technology (IT), accounting, sales and marketing, banking and finance and the healthcare and life sciences. (Williams, 2016) Cash Mart, a website, also listed some in-demand jobs in Singapore. The following jobs are Secretaries, Administrative Assistants, Office Support, Skilled Trades, Supervisors, Labourers, Sales Representatives, Drivers, Engineers, Accounting and Finance, Teachers and IT staff. (2016)

On the other hand, the most in-demand job in Thailand is still teaching. (Work Permits, 2015) While in Vietnam, according to HR2B Recruitment, the greatest demand has been the candidates in: Sales, Information Technology, Business Development, Accounting, Marketing, Engineering, Human Resources, Manufacturing, Quality Control, Administration/Secretarial and Medical and Health. But bear in mind that in Vietnam, Vietnamese workers are taken priority. Foreigners may be employed but it only happens when there is no other local alternative. (Just Landed, 2016)

Out of these information, Table 23 shows the mentioned jobs in each ASEAN-member states.

\begin{tabular}{|c|c|}
\hline COUNTRY & IN-DEMAND JOBS \\
\hline Brunei & Nursing (Male) \\
\hline Cambodia & Psychology \\
\hline Indonesia & $\begin{array}{l}\text { Asset Managers } \\
\text { Investment Bankers } \\
\text { Insurance Specialist }\end{array}$ \\
\hline Lao PDR & $\begin{array}{l}\text { Garment Industry } \\
\text { Processing Industry } \\
\text { Tourism } \\
\text { Steel Industry } \\
\text { Furniture Industry } \\
\text { Construction Industry }\end{array}$ \\
\hline Malaysia & $\begin{array}{l}\text { Chief Financial Officer } \\
\text { HR Business Partners } \\
\text { Compensation and Benefit Specialist } \\
\text { IT Support Specialist } \\
\text { Engineering Manager (Oil Gas) } \\
\text { Development Geologist } \\
\text { Drilling Engineer } \\
\text { Sales Manager } \\
\text { Social Media Manager } \\
\text { Business Development Manager } \\
\text { Data Scientist } \\
\text { Web Designers and Developers } \\
\text { Personal Financial Advisers } \\
\text { Personal and Home Care Aides } \\
\text { Marketing Managers } \\
\text { Information Security Analyst }\end{array}$ \\
\hline Myanmar & $\begin{array}{l}\text { Accounting } \\
\text { Sales }\end{array}$ \\
\hline
\end{tabular}




\begin{tabular}{|c|c|}
\hline & $\begin{array}{l}\text { IT/Software } \\
\text { Education/Training } \\
\text { Admin }\end{array}$ \\
\hline Philippines & $\begin{array}{l}\text { Doctors } \\
\text { Engineers } \\
\text { Accountants } \\
\text { Computer Programmers } \\
\text { Draftsmen } \\
\text { Animators } \\
\text { Agriculturists } \\
\text { Electricians } \\
\text { Teachers } \\
\text { Sugarcane Farming } \\
\text { Domestic Helpers } \\
\text { Service Crew } \\
\text { Commercial Sales Representative } \\
\text { Customer Service Assistants } \\
\text { Credit and Collection Specialist } \\
\text { Cashiers } \\
\text { Staff Nurses } \\
\text { Cooks } \\
\text { Sewers } \\
\text { Production Machine Operators } \\
\text { Salesclerk } \\
\text { Waiter } \\
\text { Metal Arc Welder } \\
\text { Security Guard }\end{array}$ \\
\hline Singapore & $\begin{array}{l}\text { IT } \\
\text { Accounting } \\
\text { Sales and Marketing } \\
\text { Banking and Finance } \\
\text { Healthcare and Life Sciences } \\
\text { Secretaries } \\
\text { Administrative Assistants } \\
\text { Office Support } \\
\text { Skilled Trade } \\
\text { Supervisors } \\
\text { Labourers } \\
\text { Sales Representatives } \\
\text { Drivers } \\
\text { Engineers } \\
\text { Teachers }\end{array}$ \\
\hline Thailand & Teachers \\
\hline Vietnam & $\begin{array}{l}\text { Sales } \\
\text { IT } \\
\text { Business Development } \\
\text { Accounting } \\
\text { Marketing } \\
\text { Engineering } \\
\text { Human Resources } \\
\text { Manufacturing } \\
\text { Quality Control } \\
\text { Administration/Secretariat } \\
\text { Medical and Health }\end{array}$ \\
\hline
\end{tabular}


Table 23. In-demand Jobs in each ASEAN member states

The researchers organized and classified the jobs according to the type of occupation as provided by the International Labour Organization (ILO) and the result is provided in Table 24.

\begin{tabular}{|c|c|}
\hline Occupation & In-demand Jobs \\
\hline Managers & $\begin{array}{l}\text { Social Media Manager } \\
\text { Business Development Manager } \\
\text { Sales Manager } \\
\text { Engineering Manager (Oil Gas) } \\
\text { Marketing Manager }\end{array}$ \\
\hline Professionals & $\begin{array}{l}\text { Psychology } \\
\text { Data Scientist } \\
\text { Nursing } \\
\text { Compensation and Benefit Specialist } \\
\text { IT } \\
\text { Web Designers and Developers } \\
\text { Software Developers } \\
\text { Doctors } \\
\text { Information Security Analyst } \\
\text { Environmental and Waste Management Engineers } \\
\text { Development Geologist } \\
\text { Healthcare and Life sciences } \\
\text { Engineers } \\
\text { Credit and Collection Specialist } \\
\text { Insurance Specialist }\end{array}$ \\
\hline Technician and Associate Professionals & $\begin{array}{l}\text { Technicians } \\
\text { Investment Bankers } \\
\text { Banking and Finance }\end{array}$ \\
\hline Clerical Support Workers & Secretaries \\
\hline Service and Sales Workers & $\begin{array}{l}\text { Personal and Home Care Aides } \\
\text { Cooks } \\
\text { Customer Service Assistance } \\
\text { Cashiers } \\
\text { Salesclerk } \\
\text { Waiter } \\
\text { Commercial Sales Representatives } \\
\text { Service Crew } \\
\text { Sales Representatives } \\
\text { Security Guard }\end{array}$ \\
\hline Skilled Agricultural, forestry and Fishery Workers & $\begin{array}{l}\text { Agriculturist } \\
\text { Sugarcane Farming }\end{array}$ \\
\hline Craft and Related Workers & $\begin{array}{l}\text { Garment } \\
\text { Metal Arc Welder } \\
\text { Sewers } \\
\text { Draftsmen } \\
\text { Animators } \\
\text { Construction Workers } \\
\text { Furniture Makers }\end{array}$ \\
\hline Plant and Machine Operators, Assemblers & $\begin{array}{l}\text { Production Machine Operators } \\
\text { Drivers }\end{array}$ \\
\hline Elementary Occupation & $\begin{array}{l}\text { Domestic Helpers } \\
\text { Labourers }\end{array}$ \\
\hline Armed Forces Occupation & ---- \\
\hline
\end{tabular}


Table 24. In-demand Jobs according to Classification of Occupations

The researchers also combined and tallied the in-demand jobs according to the times it is mentioned in each ASEAN member states and the result is shown in Figure 6.

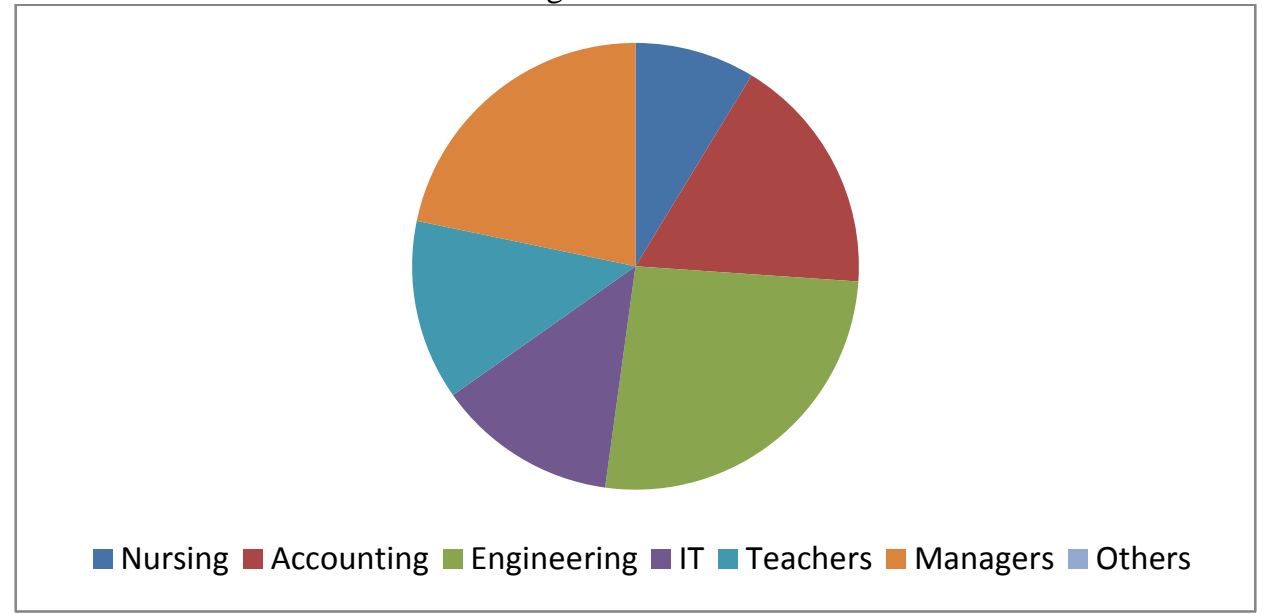

Figure 6. Tallied in-demand jobs

In this chapter, the summary of the research and the conclusion are presented. Recommendations for upcoming researches are also offered by the researchers.

\section{SUMMARY}

As the ASEAN Community 2015 was implemented, the Southeast Asian region became a single market. This means that there is a free flow of goods, skilled workers and products between the ASEAN member states. With these, job-seekers from different ASEAN member states can now work in the Philippines while Filipinos can also work abroad. The ten-year curriculum of the Philippines was replaced by the K to 12 Program for the graduates of the old curriculum were still unequipped in the workplace.

In this study, the researchers used secondary data. The ten-member states are the respondents of this study, thus, information about these states were garnered by the researchers. The main aim of this study is to produce a list of in-demand jobs in each ASEAN member states to be a guide to Filipino job-seekers in their quest of finding jobs within the Philippines or abroad if they wish to in the year 2017. To come up with the list, the researchers first did an in-depth research about the ASEAN member states of their background profiles alongside their education system. The employment and unemployment rate were also gathered and analyzed by the researchers.

The review of related literature tackled about the reason behind why $\mathrm{K}$ to 12 was implemented and how important it is in the ASEAN Integration. The background of Association of Southeast Asian Nations is also given alongside its ten-member states. ASEAN Economic Community was also talked about. Opinions from different officials and infamous people about these topics were also compiled and provided.

With the help of the secondary data, the researchers found out that most of the education system of the ASEAN member states has either 11-year or 12-year curriculum. The Philippines also has a high unemployment rate although it has the second largest population in Southeast Asia. A list of in-demand jobs were also produced at the end of the study.

\section{CONCLUSIONS}

With the creation of ASEAN Economic Community, the member-states including the citizens will be able to join in the free flow of capital, labor, services, goods, and foreign investments. In this research, the researchers acquired data from the 10 member of the ASEAN to know the in-demand jobs in each ASEAN-member states and list the possible jobs the Filipinos can apply either locally or abroad in 2017.

The 10 countries have different enrolment rate, survival rate of students in primary, secondary, and tertiary level, employment rate, supply, skills, wages and productivity. Singapore has the highest money wage while Lao PDR has the lowest. With regards to the labor productivity, Brunei is the highest, followed by Singapore then Malaysia. Out of the 10 member-states of ASEAN, Indonesia has the highest number of unemployed youth and followed by the 
Philippines. But on the contrary, Indonesia, having the largest population, has the largest total of employment rate. The country which has the lowest number of unemployed number of youth is Thailand. Philippines which has the second largest population falls fourth in the employment rate. Despite having the second largest population of the ASEAN members, the Philippines still falls in fourth of the employment rate.

The reason for this may be because of the 10-year curriculum of the Philippines before. Being a competitive country and as a member of the ASEAN, the implementation of K-12 Program in the Philippines is a big help to the country in the competition in entering the labor force. Filipino professionals will be more prepared for work. The graduates of the new curriculum will have a bigger chance of being employed.

The 10 members of ASEAN have different in-demand jobs in their country. From all the in-demand jobs of the different ASEAN member-states, the most in-demand job in Southeast Asia is engineering followed by manager, accounting, teaching, nursing, and IT. Locally, in the Philippines, the in-demand jobs are Doctor, Engineering, Accounting, Computer Programming, Draftsman, Animating, Agriculturist, Electrician and Teaching.

\section{RECOMMENDATIONS}

The purpose of this study is to know the in-demand jobs in each ASEAN-member states and the possible jobs the Filipinos can apply in the year 2017. The researches recommended study on the in-demand jobs of the ASEAN countries beyond 2017. Also, a study to compare the number of graduates in 2017 and their courses taken of the 10 Southeast Asian countries is recommended. After acquiring the exact number of college students, their courses will be compared to know what course has the highest number of takers. From the data acquired, the researches will be able to know the course would have the biggest competition. The bigger number the students who take the course, the bigger the chance of being employed. The recommended study's purpose is to know what course is best to take and would have the bigger chance of getting employed in other Southeast Asian countries.

\section{REFERENCES}

1. Abueva, A. (2015, September 2). Why Does the Philippines Need the K-12 Education System? Retrieved from https://soapboxie.com/social-issues/The-Implementation-o-the-K-12-Program-in-the-Philippine-Basic Education- Curriculum

2. Afterschool.my. (2013).Courses that lead youth to the most in-demand jobs in Malaysia. Retrieved from: http://afterschool.my/news/courses-that-lead-you-the- most-in-demand-jobs-in-malaysia/

3. ASEAN Up. (2016, February 25). Benefits of the ASEAN Economic Community - AEC Retrieved from: http://aseanup.com/benefits-asean-economic-community-aec/

4. ASEAN.(2015). ASEAN Statistical Yearbook 2014. ISBN 978-602-0980-15-4

5. Asian Development Bank. (2015, October).Summary of Indonesia's Education Sector Assesment. Creative Commons Attribution

6. Bianc, J. (2016, April 2). List of In-demand Jobs in the Philippines 2016. Retrieved from: http://newsfeed.ph/news/sugarcane-farming-2nd-in-demand-job-in-the-philippines/

7. Cervantes, F. M. (2016, June 7). K-12 needed to improve competitiveness amid ASEAN integration - Briones. Retrieved from http://interaksyon.com/article/128740/k-12-needed-to-improve-competitiveness-amid-aseanintegration---briones

8. Goyer, J. (2013, September 21). Why the 2015 deadline for the ASEAN economic integration? Retrieved from: http://www.rappler.com/world/regions/asia-pacific/39481-apb-survey-asean-economic-integration

9. ILO and ADB. (2015). ASEAN community 2015: Managing Integration for better jobs and shared prosperity. Bangkok, Thailand

10. Jaafar, J. (2016, January 8). Work it, baby: Top jobs in Malaysia in 2016. Retrieved from: http://www.freemalaysiatoday.com category/leisure/2016/01/08/work-it- baby-top-jobs-in-malaysia-in-2016/

11. Ministry of Education.(2008, November). The Development of Education National Report:Brunei Darussalam

12. Ministry of Education.(2016). Malaysia. Retrieved from: www.moe.gov.my/enrolment

13. Motte-Munoz, H. (2016, February 28). In-demand and hard to fill: Jobs to consider and prepare for. Retrieved from: http://www.rappler.com/nation/136758-senior-high-school-enrolment-one-million

a. OECD/Asian Development Bank. (2015). Education in Indonesia: Rising to the Challenge. OECD Publishing, Paris Pacete, V. (2015, April 21). Asean Integration and K-12 program. Retrieved from http://www.sunstar.com.ph/bacolod/opinion/2015/04/21/asean-integration-and-k-12-program-403520

14. Phearon, C. And Sokunthea, H. (2013, August 21). Unpopular subjects with high demand in the job market. Retrieved from: www.phnompenhpost.com/lift/unpopular-subjects-high-demand-job-market 
15. Presidential Communications Development \& Strategic Planning Office. (2012, November 30). The K to 12 Basic Education Program. Retrieved from http://www.gov.ph/k-12-old/

16. The Brunei Times. (2015, July 29). MoH: We need more male nurses. Retrieved from: http://www.bt.com.bn/news-national/2015/07/29/moh-we-need-more-male-nurses

17. The Jakarta Post. (2015, March 15). Survey: Demand for white-collar professional to grow in Indonesia. Retrieved from: www.thejakartapost.com/news/2015/03/15/survey-demand-white-collar- professionalsgrow-indonesia.html

18. Thompson, M. (2016, March 15). Employment Trend: Vietnam Retrieved from: http://www.goingglobal.com/articles/1661/

19. UNESCO. (2015). Education for All 2015 National Review Report: Cambodia

20. UNESCO. (2015). Education for All 2015 National Review Report: Malaysia

21. UNESCO. (2015). Education for All 2015 National Review Report: Philippines

22. Uyguiengco, M. (n.d.). Benefits of the K-12 curriculum for Filipino students! Retrieved from https://ph.theasianparent.com/advantages-new-k-12-curriculum/3/

23. Valente, C. (2013, October 26). Asean integration in 2015 and its implications on labor Retrieved from: http://www.manilatimes.net/asean-integration-in-2015-and-its-implications-on-labor/47994/

24. Vandenbrink, R. (2013). Laos to Allow Tens of Thousands More Foreign Workers. Retrieved from: http://www.rfa.org/english/news/laos/labor-09242013152345.html

25. Williams, A. (2016, May 4). What are the hot jobs in Sngapore in 2016? Here are 5 highest-paying sectors. Retrieved from: http://www.straitstimes.com/business/economy/what-are-the-hot-jobs-in-singapore-in-2016here-are-5-highest-paying-sectors

26. Work.com.mm. (2015). Accounting and Finance jobs ranked high in demand. Retrieved from: https://www.work.com.mm/en/career-report-august-2015.html

27. Worldmeters.(2016). World Population. Retrieved from: www.worldometers.info 